\title{
THE NECESSITY OF IMPROVING CULTURAL AWARENESS OF EFL LEARNERS IN STMIK HANDAYANI MAKASSAR
}

\author{
Yuliah, S.S, M.Hum \\ STMIK Handayani Makassar \\ yyuliah@rocketmail.com
}

\begin{abstract}
This paper mainly discusses the relationship between language and culture. Language and culture are closely related. If one does not understand the cultural backgrounds, he or she cannot learn the target language really well because any language is an integral part of its culture. Moreover, misunderstanding between the speaker whose first language is English and the speaker whose first language is not English occur between them. The writer believes that there is still an important cultural element missing from foreign language education in Indonesian EFL classes in such as in STMIK Handayani Makassar. Therefore, English learning in STMIK Handayani Makassar should not only to learn the language, but also to learn its culture. To improve students' sensitivity for cultural difference between the West and the East and to raise their cultural awareness, English teachers at schools are required not only to teach language but also to impart cultural background knowledge and further to deal with the relationship between language and culture well. This article starts with the necessity of teaching cultural awareness in English teaching at schools, and then this paper discusses some common cultural language mistakes by English Foreign Language learners in STMIK Handayani Makassar.
\end{abstract}

Keywords: EFL learners, culture, cultural awareness, students' sensitivity, and Language.

\section{A. INTRODUCTION}

$\mathrm{I}$

$\mathrm{t}$ is generally agreed that language and culture are closely related. Language and its culture cannot be taught separately in any foreign language program. Language can be viewed as a verbal expression of culture. We all know that understanding a language involves not only knowledge of grammar but also a certain features and characteristics of the culture. To communicate internationally inevitably involves communicating interculturally as well, which probably lead us to encounter factors of cultural differences. Such kind of difference exists in every language such as the place of act functions. For example, apologizes, refusals, suggestions, gives and accept compliment, etc. Many of students who learn English still give responses based on their culture when they speak in English. Therefore, through this research the writer will discuss the necessity of improving cultural awareness of EFL learners and discuss some cultural language mistakes among the students of STMIK Handayani Makassar.

The previous researches in the same field had been done such as Nguyen (2017) in her research Integrating Culture into Language Teaching and Learning: Learners Outcomes and Choudury (2013) in his 
research Teaching Culture in EFL: Implications, Challenges and Strategies. Both the researches emphasized on the discussion about the challenges faced by teachers while teaching target culture but not emphasizes on the analysis of the cultural language mistakes that are done by the learners. Through this research the researcher will discuss the cultural language mistakes among the students of STMIK Handayani Makassar as the learners of EFL to improve the students' cultural awareness in learning English as a Foregn Language.

To fully function in a particular language, students need to understand not only the form of the language, such as the grammar, but also to use that form in its appropriate cultural contexts. Unfortunately, foreign language instruction in Indonesian classes is focused solely on linguistic competence which very often centers on the form of the language. Consequently, the development of students' communicative abilities cannot occur even though the students have learnt the foreign language since they are at elementary schools. Silberstain (2001, p.103) states that "Grammatical knowledge alone does not guarantee communication." Instead, the focus should include teaching students the social and cultural aspect of the target language.

Teachers must instruct their students on the cultural background of language usage. If one teaches language without teaching about the culture in which it operates, the students are learning empty or meaningless symbols or they may attach the incorrect meaning to what is being taught. The students, when using the learnt language, may use the language inappropriately or within the wrong cultural context, thus defeating the purpose of learning a language.

\section{B. LITERARY REVIEW}

\section{Language}

Language is a tool for communication to interact with other people, to express our feeling, idea, and concept in our mind. Language is a system which means language is formed by a number of components which has a pattern and can be understood. According to Sapir (1921), "language is a purely human and non-instinctive method of communicating ideas, emotions and desire by means of voluntarily produced symbols." Language is a part of culture and a part of human behavior.

It is often held that the function of language is to express thought and to communicate information. Language also fulfills many other tasks such as greeting people, conducting religious 
service, etc. Krech ( 1962 ) explained the major functions of language from the following three aspects:

1). Language is the primary vehicle of communication;

2). Language reflects both the personality of the individual and the culture of his history. In turn, it helps shape both personality and culture;

3). Language makes possible the growth and transmission of culture, the continuity of societies, and the effective functioning and control of social group.

It is obvious that language plays a paramount role in developing, elaborating and transmitting culture and language, enabling us to store meanings and experience to facilitate communication. The function of language is so important in communication that it is even exaggerated by some scholars. The most famous one is the hypothesis of linguistic determinism concerning the relationship between language and culture, which Nida regards as misconceptions constituting serious difficulties for cross-cultural understanding.

\section{Culture}

Culture may mean different things to different people. It is worth mentioning that the term 'culture' is so vague. It may embrace different concept given by different scholars belonging to several fields of study such as anthropology, ethnography, literature, cultural studies, etc. Culture is the characteristics and knowledge of a particular group of people, defined by everything from language, religion, cuisine, social habits, music and arts.

The Center for Advance Research on Language Acquisition goes a step further, defining culture as shared patterns of behaviors and interactions, cognitive constructs and understanding that are learned by socialization. Thus, it can be seen as the growth of a group identity fostered by social patterns unique to the group.

The word "culture" derives from a French term, which in turn derives from the Latin "colere," which means to tend to the earth and grow, or cultivation and nurture. "It shares its etymology with a number of other words related to actively fostering growth," Cristina De Rossi, an anthropologist at Barnet and Southgate College in London, told Live Science.

In the anthropological sense, culture is defined as the way people live (Chastain, 1988, p. 302). According to Brown (1994, p. 170) culture is deeply ingrained part of the very fiber of our being, but language -the means for communication among members of a culture- is the most visible and available expression of that culture. And so, a person's world view, self-identity, and system of 
thinking, acting, feeling and communicating can be disrupted by a change from one culture to another. Similarly, Tang (1999) propounds the view that culture is language and language is culture. He suggests that to speak a language well, one has to be able to think in that language, and thought is extremely powerful. Language is the soul of the country and people who speak it. Language and culture are inextricably linked, and as such we might think about moving away from questions about the inclusion or exclusion of culture in foreign language curriculum, to issues of deliberate immersion versus non-deliberate exposure to it.

\section{Cultural Awareness}

Culture awareness has become an important focus of modern language education, a shift that reflects a greater awareness of the inseparability of language and culture, and the need to prepare students for intercultural communication.

Cultural Awareness is the foundation of communication and it involves the ability of standing back from ourselves and becoming aware of our cultural values, beliefs and perceptions. Why do we do things in that way? How do we see the world? Why do we react in that particular way? Cultural awareness becomes central when we have to interact with people from other cultures. People see, interpret and evaluate things in different ways what is considered an appropriate behavior in one culture is frequently inappropriate in another one. There are varying definitions of cultural awareness. The NCCC defines "cultural awareness" as being cognizant, observant, and conscious of similarities and differences among and between cultural groups (Goode, 2001, revised 2006).

According to Winkelman (2005), awareness of cultural differences and their impact on behavior is the beginning of intercultural effectiveness. He states that "cultural self-awareness includes recognition of one's own cultural influences upon values, beliefs, and judgements, as well as the influences derived from the professional's work culture."

\section{The Necessity of Cultural Awareness in English Learning}

In modern society, with the globalization of the world, contacts in all sorts of fields, such as, economy, science and technology become more and more frequent. It is enviable for people around world to communicate with those from another culture. To avoid unexpected misunderstanding, which is caused by ignorance of cultural differences, it is important to carry on culture teaching. Since language is inseparable from culture, culture teaching indivisible from English language 
teaching. Although educators have been aware of the necessity of culture teaching, it is not popularized in education.

The advantages of culture teaching are easily found in the whole English teaching program. Firstly, culture teaching does great good to language acquisition in learning language itself. As we discuss above, the English structure and expression are related to culture, thus, culture teachings will certainly a beneficial subsidiary to English language teaching. The procedure of culture learning is at the same time of the developing of language ability. Secondarily, culture teaching satisfies students' curiosity about the totally different environment of the other country. What English learners want to learn about is not just the sign of the language, but the people and the nation in which the language is used. Increasing learners' sensibility to cultural factor, educators can make use of their curiosity and motive to achieve the goal of language teaching. Thirdly, the learning of a new language involves in not only meaning between words, sentences and text but also an interaction between knowledge and experience and new things.

Learning English well does not simply mean to grasp its grammar, pronunciation, and vocabulary, it also means to learn the culture that reflects ideas, customs, life styles, and beliefs. Therefore, leaning English is inseparable from learning its culture. Culture reflects a nation's characteristic, it does not only include its history and culture background, but also contain its outlook of life, their life styles and ways of thought (Deng \& Liu, 1989). HU (1989) also pointed out that culture learning and language learning should be conducted simultaneously. Otherwise, culture will come apart with language. And the problem of culture is more serious than language itself. So it is obvious that cultural awareness cultivation is quite important in English learning since they cannot be separated by each other. If learners learn the letter itself but ignore the meanings remained it under cover, it will be with great difficulties to learn a language well. It is known that grammar failure can be easily found by the hearer and still can be accepted by the hearer. However, pragmatic failure is treated differently. If the speaker uses the phrases improperly, the hearer will think that he/she is not polite. Culture can also broaden learners' horizon, and the aims at English learning are to develop their ability to use English they are learning properly.

Language is the carrier of culture and cultural awareness can improve learners' understanding of the culture of English-speaking countries. In order to truly understand a language, English learners should have a deep comprehension of the culture background information about the target language. The enhancement of cultural awareness may promote the English speaking competence 
and understanding. However, most young guys are very bashful in expressing their emotion to their lovers. People will not say "I love you" directly. They will find another way to express this feeling. Young girls will pray god for a very happy family. Young girls will not express their wishes directly.

The reason why people are introverted and indirect is that people are influenced by the Confucianism and the feudal ideology. Confucianism advocates that "the enjoyment is expressed without being licentious and the grief is expressed without hurtfully excessive” (Zhu, 2007, p. 163). The feudal ideology is conservative. Both of them affect people's character.

From this point of view, language learning, including culture learning provides a good opportunity to widen students' horizon of knowledge.

\section{METHODOLOGY}

This section consists of two subsections: participants and procedure, each of which is given a detailed account below:

a. Participants

The participants of this research were the students of STMIK Handayani Makassar who were learning Basic English on semester one. The number of participants were 34 students of Information Technology.

b. Procedure

This research used qualitative methodology. The procedure began by design questions or statements that the students should answer or response the questions or the statements which is about giving compliment, addressing someone, invitation, telling past activity, expressing dislike, and expressing feeling. To get the answers and the responses of the students the researcher asked the questions to the students as the data of this research by interviewing them. The data then were analyzed to show the mistakes that the students made.

\section{FINDINGS ND DISCUSSION}

Anyone who speaks a language that is not their first is going to make mistakes. It's a universal phenomenon. But if we look at particular cultural and linguistic groups, we can notice certain specific kinds of mistakes common to that group. The following examples are the common cultural language mistakes among EFL learners in STMIK Handayani Makassar.

1. A: You look beautiful. 
Volume 5, Number 01, June 2019

\section{B: Really (Incorrect)}

Thank you for your compliment. (Correct)

Here the speaker B gives inappropriate response when he gets a compliment from speaker A. B seems does not believe if she is beautiful. In English when someone gets a compliment she should thanked for the compliment on her.

2. A: Your watch is nice.

B: This is a cheap watch. (Incorrect)

Oh, Thanks. (Correct)

Here the speaker B also gets a compliment on her watch but he does not response by saying thank you.

3. A: Let's have dinner.

B: Yes, thanks. I am full. (Incorrect)

No, thanks. I am full. (Correct)

Here the speaker was offered to join the dinner but he rejected the offer because he was full. In English when we reject an offer, we should say No, thanks but the speaker said Yes, thanks. It is because of the culture in Makassar that always says 'Yes' to be polite in rejecting an offer.

4. Wow, You look so young. (Incorrect)

Wow, You look great for your age. (Correct)

Here the speaker uses a phrase to tell someone that he looks great for his age. However, he used incorrect phrase by saying 'You look so young'. It is because of the influence of culture.

5. Hello, Mister. (Incorrect)

Hello, Sir. (Correct) 
People in Makassar usually address a tourist Mister without including his name. In English addresses someone with Mr without including his name is impolite. The polite word to address a man in English is 'Sir'

6. Do you ever go to Bali? (Incorrect)

Have you ever been to Bali? (Correct)

The learners in STMIK Handayani Makassar have problem with Present Perfect. When they ask someone whether he/she has ever been to a place, they use Simple Present which is caused of their culture instead of Present Perfect Tense.

7. I cut my hair yesterday. (Incorrect)

I had my hair cut yesterday. (Correct)

The learners in STMIK Handayani Makassar usually make mistakes when they want to express something done by someone. 'I cut my hair' means I do it myself. 'I have my hair cut' means someone cuts my hair for me (in this case it's probably a hairdresser).

8. I go to Mall yesterday. (Incorrect)

I went to Mall yesterday. (Correct)

Another mistake among the learners in STMIK Makassar when they speak in English is tense confusion. They have no separate markers for tenses. Everything is said in the present tense. When they talk about something happens in the past they express it in present.

9. A: I don’t like Rock music.

B: Me too. (Incorrect)

I don't either. (Correct)

Another problem which causes the learners makes mistakes when they speak in English is the problem with determiner. They use 'too' for negative statement. It is because of the influence of their culture when they express their agreement or disagreement on an idea by using the same word which is 'too' for negative or positive statement. 
Volume 5, Number 01, June 2019

10. A: You didn't attend the class yesterday, did you?

B: Yes. (Incorrect)

No. (Correct)

The learners in STMIK Handayani Makassar also have problem with the tag questions. They are influenced by their culture which always says 'Yes' for the negative statement.

11. A: I am boring to go to the canteen. (Incorrect)

I am bored to go to the canteen. (Correct)

B: Why?

A: The food are same everyday.

The students use -ing instead of -ed to express their feeling. In some contexts, the sentence would be perfectly correct, but the chances are that students usually mean 'I am bored'. Mixing up -ing and -ed participles is a huge source of confusion: those ending in -ed describe how people feel and those ending in -ing describe the things or people cause those feelings.

Based on the findings, the mistakes that were done by the students are commonly caused by the influence of their habit in using their first language to respond the language that they are learning. Such as when someone gives complements, they do not say thank you, the use of 'yes' when refuse invitation or offering and the use of Present Simple Tense in expressing past activities.

\section{E. CONCLUSION}

Language is a major component and supporter of culture as well as a primary tool for transferring message, which is inextricably bound with culture. Learning a second language also involves learning a second culture to varying degrees. On the other hand, language is influenced and shaped by culture. It reflects culture. Cultural differences are the most serious areas causing misunderstanding, unpleasantness and even conflict in cross-cultural communication. So both foreign language learners and teachers should pay more attention to cultural communication information. 
Language and the application of language cannot be separated from culture. If one wants to learn language well, he/she must understand culture. The special relationship between language and culture requires learners to realize the importance of culture fully while they gain language. Therefore, English teachers should not only develop students' four basic English skills, namely, listening, speaking, reading, and writing, by imparting language knowledge, but also intensify their cultural awareness by a variety of effective ways. They should try their best to intensify students' cultural awareness while developing their language ability. Cultural knowledge should be introduced throughout the whole language teaching. In doing so, students can avoid making mistakes in crosscultural communication and improve the quality of English learning.

From the cultural point of view, that kind of teaching method compensates the traditional foreign language teaching's shortage. During the process of imparting cultural background knowledge, teachers who play an important role should teach cultural knowledge of Englishspeaking countries according to students' learning needs. In order to make students know about cultural values of English-speaking countries and the way of their life, teachers should use effective teaching methods to intensify their cultural awareness, such as by making good use of teaching materials, helping students compare the cultural difference on vocabulary, and encouraging students to take part in extra-curricular activities.

\section{REFERENCES}

Brown, H.D. (1994). "Principles of Language Learning and Teaching." The USA: Prentice Hall Regents.

Chastain, K. (1998). Developing Second Language Skills. The USA: HBJ Publishers.

Choudhury, Murshed Haider. (2013). Teaching Culture in EFL: Implications, Challenges, and Streategies. King Khalid University, Saudi Arabia.

Deng,Y. C., \& Liu, R. Q. (1989). Language and culture. Beijing: Foreign Language Teaching and Research Press.

Goode, T. 2001 (revise 2006). Key definition. Washington D.C.: National Center for Cultural Competence, George Town University Center for Child and Human Development.

Nguyen, Trang Thi Tuy, (2017). Integrating Culture into Language Teaching and Learning: Learner Outcomes. Kon Tun College, Vietnam.

Sapir, Edward.(2000). Language: An Introduction to the Study of Speech. New York. Bartleby.com. 
Volume 5, Number 01, June 2019

Silberstein, S. (2001). Sociolingistics, In R. Carter and D. Nunan (eds) the Cambridge Guide to Teaching English to Speakers of Other Languages. Cambridge: Cambridge University Press.

Tang, Romana. (1999). The Place of "Culture" in the Foreign Language Classroom: A Reflection. The Internet TESL Journal, Vol. V, No. 8, August 1999. http://iteslj.org/Articles/TangCulture.html.

Winkelman, M. (2005). Cutural Awareness, Sensitivity \& Competence. Peosta, Lowa: Eddie Bowers Publishing Co, Inc.

ZHU, Z . L. (2007). Confucian classics. Beijing: Changan Press 